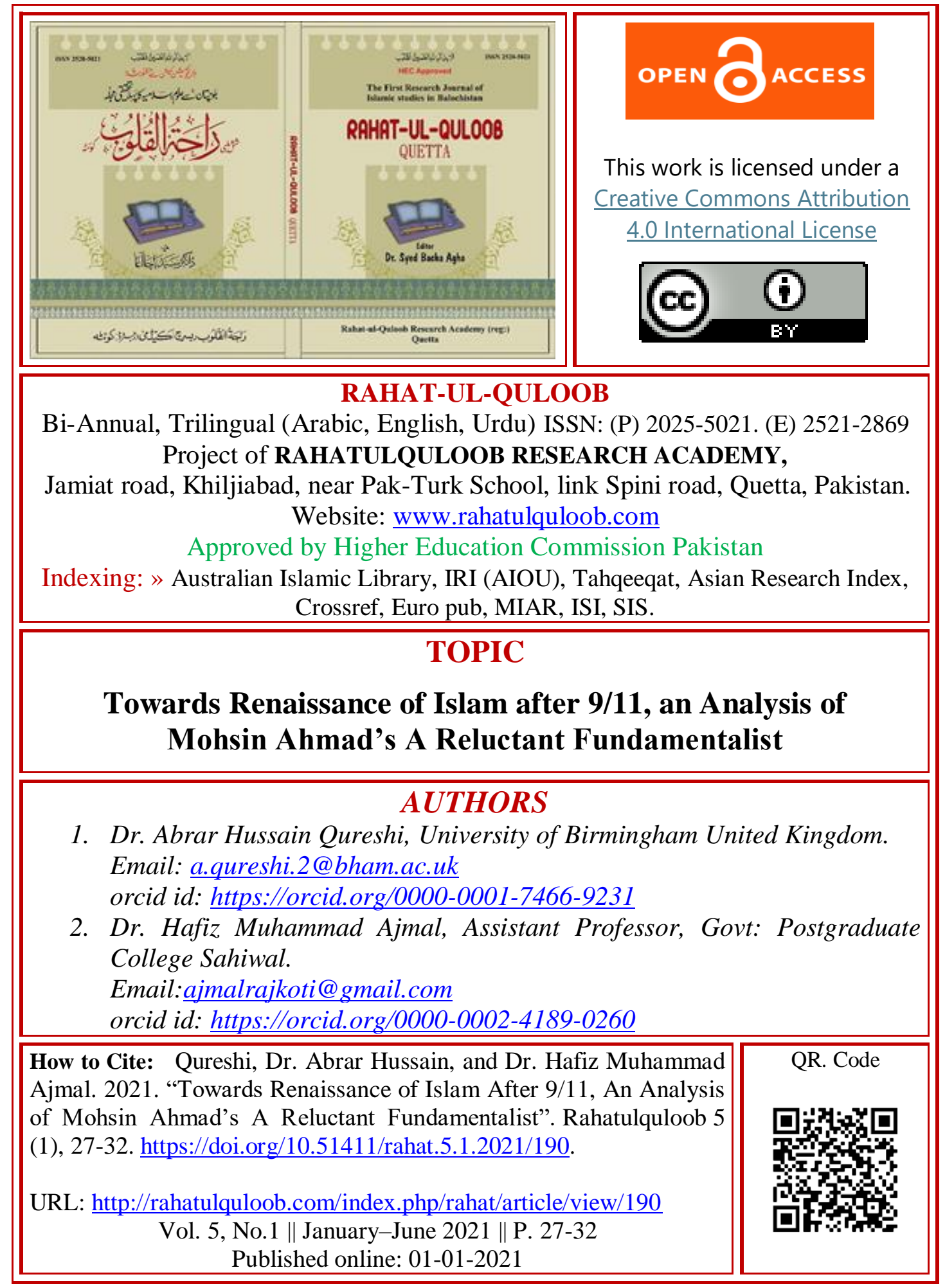




\section{Towards Renaissance of Islam after 9/11, an Analysis of Mohsin Ahmad's A Reluctant Fundamentalist}

\section{ABSTRACT}

${ }^{1}$ Abrar Hussain Qureshi, ${ }^{2}$ Muhammad Ajmal

The political and theological scenes took a drastic change in the Muslim Ummah of Asia and to some extent in Europe and America after the September 11, 2001 attacks on the twin towers. It seriously affected the Muslims populated regions and the Diasporas stretching from East to West ${ }^{1}$. Apparently, Islam faced many threats from the secular West in the form of socio-political sanctions. However, this catastrophic incident also ignited in Muslims to review their Muslims identity and to launch an organized effort to establish the real identity of Islam. The undertaken investigation is an attempt in this regard that how the protagonist Changez in Mohsin Ahmad's "Reluctant Fundamentalist" shapes into a Islamic fundamentalist after 9/11 attacks and comes back to Pakistan although he was a having a promising career in America that time.

Keywords: Islam, Culture, Attacks, Renaissance, Identity.

\section{Introduction:}

The real spirit of Islam is that it strongly advocates harmony between political, cultural and religious forces. With the advent of enormous advancement in the means of communication and transportation, there has been felt an irresistible urge to adopt universal laws and values for the peaceful relationships between communities and cultures. United Nations tried to fulfill this gap through America and motivated different cultures to adopt American World Order because up to the start of the $21^{\text {st }}$ century America was the only super power from military and economic perspectives ${ }^{2}$. This imperialistic attitude towards other nations and cultures of the world put their solidarity in danger. Americans, in order to fulfill their national interests used fair or foul means to dominate weak cultures and nations that belonged to other religions as well. Americans used even international institutions, military power and economic resources to maintain her dominance. Accepting this new aggressive world order was not easy for all the nations and cultures of the world because it was leading towards a secular and materialistic view of life. According to Shlzinger ${ }^{3}$, most of the people considered this absolutely unproductive and away from civilization though opposing this ideology meant strong resistance from American Imperialism. The most severe victimization that resulted in opposing American interest in the world was against Islam. Manny tactics including international media were employed to show Islam as the religion of terrorism. An unending crusade was launched in Asia especially inn Middle East to protect Americans interests worldwide. Muslim countries were attacked in the name of terrorism. There was a hidden conspiracy to weaken Muslim countries militarily and economically. International governments even used such lethal tactics as to motivate the Muslims to wage war against their own brother Muslim countries. ${ }^{4}$ Asserts that the most dangerous phenomenon in this regard was the 9/11 
attacks that absolutely changed the whole profile of Muslims in the world and they were outwardly labeled as terrorist. Islam was started to be considered as the religion of terrorism. But this dismal situation had also a blessing in disguise. There was felt an unending urge among the Muslims to step up and try to blot tout the stigma of terrorism against Islam. There was a formal attempt to convey the real message of Islam to the world. In other words a true renaissance started to inject a new life in the demoralizing scenario of Islamic culture and civilization.

\section{Statement of the Problem}

The undertaken research explores the issue of Islamic renaissance after the catastrophe of 9/11 by keeping in view its impact on Islam in modern era. The novel "The Reluctant Fundamentalist" by Hamid ${ }^{5}$ has been chosen to investigate the issues of Islamic renaissance in $21^{\text {st }}$ century in the reign of American hidden imperialism. Hamid presents that after 9/11 incident, when the world trade center was attacked, America starts to show discriminatory attitude towards the Muslims but the impact of this biased attitude was paradoxical on Islam and its followers. According to Leei ${ }^{6}$ "Muslims grew more firm on their Islamic ideology rather it will be better to say that Islam got a new renaissance for its survival". Through Changez, Hamid conveys the idea that America tried to distort the identities of American muslins but the protagonist sticks to his Islamic fundamentalism and survives the threatening attitude of American cultural imperialism. Changez finally decides to return to Pakistan and lead his life according to the long cherished principles of Islam, indirectly resulting in Islamic renaissance.

\section{Textual Analysis}

Modern technology has not only threatened orthodox cultural values but also the deep roots of religions across the globe. According to Peik ${ }^{7}$, this religious hijacking occurred with people in a more lethal way who left their own homelands for economic, political, or some other reasons. Nonetheless, one incident accelerated this phenomenon of religious imperialism and that was the air attacks on twin towers of America, namely 9/11 attacks ${ }^{8}$. This phenomenon, which is still facing questions on its integrity, shook the very foundations of Islam in the west and there was felt a serious urge to highlight the real spirit of Islam to the western people. The undertaken novel "Reluctant Fundamentalist" by Mohsin Ahamad is the best example in this regard that how the 9/11 incident proved havoc for the religious values of Islamic institutions and values specially in the west and how the protagonist, Changez, has to face religious biasness from his fellow colleagues in the wake of 9/11 incident, though he was a graduate from Princeton university America. He decides to leave America to save his Islamic values though he had ambitious plans to rise in United States. The analysis of the text also proves that people have to establish their religious identities when they intend to live in alien lands and that is not an easy task by any standard. Rather, there occurs a clash off religions that even tries to distort the political identities sometimes and those religious communities face comparatively more danger that are in minority in the west. The undertaken novel highlights that how do the immigrants suffer as far as their 
religious beliefs are concerned. The Novel opens with the introduction of the protagonist, Changez, who moves to United States, initially for higher education and afterwards to make his carrier. Finally, he hunts a good jobs in a well-established company naming Underwood Samson as an analyst. He works very hard in the firm and has higher plans to make his mark in the alien land. But all his plans end in smoke when the catastrophic incident of 9/11/2001 happens due to the terrorist attacks on the world trade center. Changez, is not accepted fully in the American culture in spite of the fact that he struggles hard to hide his original Muslim character and adopts the life- style of native and behaves as an American."I attempted to act and speak, as much as my dignity would permit, more like an American". The lines reflect his keenness to forget his Islamic profile and become a part of the new environment as text reveals: "His grip was firm and seemed to communicate to me, in that moment, that Underwood Samson had the potential to transform my life as surely as it had transformed his, making my concerns about money and status things of the distant past". The protagonist is satisfied and motivates this internal and external change in himself to excel in life. This highlights that he is ready to pay any price in this regard, specially, his Islamic identity. He starts accepting anti-Islamic culture and even starts drinking that is against the injunctions of Islam. On one occasion, when he is invited by his girlfriend Erica at her home, her father offers the protagonist wine in the style as he feels that Changez will likely refuse. But, when Changez accepts the offer, her father tell him about his colleague from Pakistan who did not use to drink as it was Not allowed in Islam neither culturally acceptable there. But Changez crosses all these Islamic and cultural boundaries to be a part and parcel of anti-Islamic culture of America as the following line reveals. "I was immediately a New Yorker". This cultural and religious change is so strong in him that he thinks: "On that day, I did not think of myself as a Pakistani, but as an Underwood Samson Trainee and my firm's impressive offices made me proud". This religious change can also be felt in him when he visits Manila. He hides his Islamic identity and tries to express his American attachment. He feels respected as he hides his Muslim self. But in spite of all this, the Islamic fundamentalism is present in him. His American dream ends in smoke after 9/11. His original Islamic identity is threatened as he becomes a victim of religious imperialism. His disappoint in the anti-Islamic American culture is very apparent as he is thoroughly investigated when he returns from Manila. When America attacks Afghanistan, he is annoyed. It further enhances his disillusionment in the American anti-Islamic reaction. Changez is highly suspected because of his Islamic profile .After 9\11, Islam becomes the target of hatred as the text reveals: "Pakistani cabdrivers were being beaten to within an inch of their lives; the FBI was raiding mosques, shops, and even people's houses; Muslim men were disappearing, perhaps into shadowy detention centers for questioning or worse". The above lines truly reflect the crumbling effect that Islam faced after 9/11. Changez even observes the prejudice in Erica's father's behavior when he talks about his country. His decision to return Pakistan is due to the face that his Islamic profile is in danger. Once he is 
taken as Arab and abused as "fucking Arab." He becomes the victim of hatred of the native people. Americans show discrimination, hate, racism and biased attitude for him and he has to bear all these things being Muslim. And a series of events put his Islamic identity in crisis as the following lines state: "I lacked a stable core. I was not certain where I belonged- in New York, in Lahore, in both, in neither... was so fragile."

It highlights that he feels not content with his new anti-Islamic identity. As, he is born with an Islamic identity in Pakistan, it is mingled in his blood. He feels a strong urge to search for his real Islamic self that he does not find in America. He starts recollecting his Islamic self and tries to solve the complicated issue of his real self. He repeatedly wants to hear about his homeland and tires to enliven his real self of Islamic Pakistan. He is worried when he hears that America is attacking Pakistan's Muslim neighboring country. This reflects his attachment for Islam. The love for his religion takes a new shape. He starts building his self in the background of Islamic Pakistan. He is also facing problem due to his non-native outward appearance.

Finally, after 9/11 incident, he starts getting realization of his real Islamic self. He even grows a beard to reflect his real Islamic fundamentalism. When, occasionally, he makes a visit, his mother advises him to remove the beard before leaving for America again. He knows that keeping beard in America may cause serious issues but he has got his new Islam integrity and decides to keep his beard as the following lines of the text reveal: "It was perhaps, a form of protest on my part, a symbol of my identity, or perhaps I sought to remind myself of the reality I had just left behind was deeply angry." The lines reflect that he keeps his beard because he does not want to look like as his co- workers. It expresses that his desire to assimilate in the American culture has ended forever. He separates himself from the anti-Islamic culture of America though on his return to America, he has to face severe reaction from his co-workers. He becomes a target of whispers and stares. Changez is abused as "Fucking Arab" because of his beard because the terrorists have beard.

The undertaken research also reflects that Americans and Europeans consider Islam a great threat to their prosperity. They accept the Muslims only that time when they are willing to compromise their Islamic values. Hamid asserts that American society is not absolutely free from religious prejudice. That is why Changez is considered as other by the American society. It is the reaction of the American society that he discovers his real Islamic self. He finally feels himself a stranger in an anti-Islamic culture. Instead of all his potential and intelligence, he is unable to really absorb the American culture. That's why; his friends become surprised when he tells about his dream on a holiday trip in Manila as the text reveals: "When my turn came, I said I hoped one day to be the dictator of an Islamic republic with nuclear capability; the others appeared shocked and I was forced to explain that I had been joking". The lines show this his friends are at a loss to understand his joke. This reflects the typical cross cultural and religious differences between the East and the west. Hamid highlights that the protagonist throws away his western cloak when he is treated prejudicially at 
the airport. He is stopped and separated from his colleagues and leave for America alone. "I flew to New York uncomfortable in my own face: I was aware of being under suspicion; I felt guilty...this naturally led to my becoming stiff and self-conscious". When Changez impatiently is searching for his Islamic identity, he considers himself like the Janissaries. The author presents the allusion of the janissaries to present the relationship between America and Pakistan. Janissaries were Christian boys and were trained by Roman Empire .So; they fought against their own civilization and culture to destroy them. Hamid presents Changez as a Janissary, detached from his own culture and national profile, who is ready to work for the American interests and to erase his original self. Changez assumes the role of modern janissary as the text highlights: "I was a modern-day janissary, a servant of the American empire at a time when it was invading a country with a kinship to mine". Changez's sentiments grow harder against anti-Islamic America. He expresses his hatred towards America by sticking more close to the fundamentals of Islam. After his return from America, he gets a job in a university in Pakistan. He makes serious efforts to unveil the true face of American anti-Islamic culture. He, indirectly, projects the true spirit of Islam that is based on tolerance. He tries to establish among his students the all-embracing principles of Islam.

Concluding Remarks: After a close analysis of the text, it can be safely concluded that in spite of all the organised efforts of anti-Islamic forces to disintegrate Islam, they could not be successful in their evil designs. Apparently, after 9/11, there was launched a lethal crusade against Islam by opening many war fronts in Afghanistan and in Middle East, but Islam revived in the face of all these anti-Islamic forces ${ }^{9}$. Like Changes, there were many individuals, groups, organizations, who stood to face the challenge of anti-Islamic forces with steadfastness ${ }^{10}$. To the end of the novel, Changez points out that all Pakistani and Muslims are not extremist, narrow-minded, attackers or terrorists.. In The Reluctant Fundamentalist, Hamid argues that it looks not possible that the disrespect and suspicion of America for Pakistan cannot be discarded even though a person give up his valuable thing that is his Islamic identity.

\section{References:}

${ }^{1}$ Solomn, D. (2007) the Stranger Interview With Mohsin Hamid. The New York Times.

${ }^{2}$ Keble, A. (2014). The 9/11 Novel: Trauma, Policies and identities. NewYork

${ }^{3}$ Shlzinger. K. (2010). Hamid's The Reluctant Fundamentalists. Australia Insight Publications.

${ }^{4}$ Rammanan, M. G. (2010). The West and Its Other: Literature Response Studies to 9/11 A Journal of English studies, 42

${ }^{5}$ Hamid, M. (2007) the Reluctant Fundamentalist. London: Penguinne

${ }^{6}$ Leei,R.(Ed) 2014. The Routldge Companion to Asian American \& Pacific Literature London Routldge.

${ }^{7}$ Peik, L. (2011). Behind the Backlash: Muslims America after 9/11. Phildephia; Temple Uni: Press

${ }^{8}$ Alsutany, E. (2012) Arab and Muslims in Madina: Race and representations after 9/11. New York: NYU Press.

9 Beohmer, E. \& Morton, S. (Edu) (2002). Terror and the Post-colonial: A Conncise Companionn. NewJersy: Jhon Wiley and Sons.

${ }^{10}$ MacFarland, Morey. (2011) Framinng Muslims MA: Harward University Press 